\title{
P1 正常剖検心の房室結節周囲リンパ管構造分布から推測される心サルコイドーシス発生様式
}

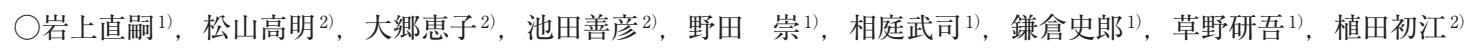

国立循環器病研究センター 心臟血管内科部門 不整脈科1)

国立循環器病研究センター 臨床検査部臨床病理科 2

【背景】心室中隔基部は心サルコイドーシス（心サ症）の好発部 位の一つで, 典型例では同部位は菲薄化し，房室ブロックの原因 になると考えられる。この部位に病変を形成する機序は不明であ り，今回我々は房室結節周囲のリンパ管分布に着目し，心症と ともに検討した.

【方法】器質的心疾患のない剖検心13例（男性8例, 平均年齢53歳） を用いた．固定後に房室伝導路を含む房室中隔後部を切り出し， 房室弁輪に水平に連続切片を作成. Podoplaninによる免疫染色 を行い, 房室結節・His束, 心房・心室接合部各部位の単位面積内 のリンパ管数を比較した.

【結果】リンパ管の分布は心房・心室中隔の心筋内にはわずか $(<1 /$ $\left.\mathrm{mm}^{2}\right)$ であったが, 房室結節 $\left(2.4 \pm 1.9 / \mathrm{mm}^{2}\right)$, His束 $(6.8 \pm 4.0 /$ $\left.\mathrm{mm}^{2}\right)$ とHis束内に多く, さらにその周囲の心臟骨格線維と一般
心室筋移行部である中隔頂上部 $\left(3.7 \pm 3.3 / \mathrm{mm}^{2}\right)$ にも多く分布を 認めた $(\mathrm{p}<0.0001)$. また, 実際に心症での分布も比較した.

【結語】心室中隔に好発する心サ症の特徵的な病変と, 房室ブロッ ク発生の機序がリンパ管の分布で説明される可能性が考えられ た.

\section{P2 心臓サルコイドーシス治療方針決定におけるFDG-PETの有用性}

○直井兵伍 ${ }^{1)}$, 井窪祐美子 ${ }^{1)}$, 東海林寛樹 ${ }^{1)}$, 宮下直也 ${ }^{1)}$, 川述剛士 ${ }^{1)}$, 田中健介 ${ }^{1)}$, 鈴木未佳 ${ }^{1)}$, 河野千代子 ${ }^{1)}$, 山田嘉仁 ${ }^{1)}$, 山口哲生 ${ }^{2)}$, 廣江道昭 ${ }^{3)}$

$J R$ 東京総合病院 呼吸器内科 1 )

JR東京総合病院 救急総合診療科 2

国立国際医療研究センター 循環器内科3)

心臟サルコイドーシス (心サ症) の診断治療において, 心筋障 害の有無抢よびその重症度の評価は重要である。Ga-67-citrate, Tl-201などによる核医学検査や造影MRIに加えて, 近年, 心开症 の画像診断における ${ }^{18} \mathrm{~F}-\mathrm{FDG}$-PETの有用性が数多く報告されてい る. しかしその検査方法や集積の意義に関しては未だ議論が多い 状態である. 今後解決すべき問題はあるが, 心臓病変を疑われて ${ }^{18}$ F-FDG-PETを施行した症例の経時的評価を試みた，対象は当院 において全身治療を導入している心サ症16例. 組織診断群 10 例, 臨床診断群6例.5例に集積陽性を認め，10例は集積なし，1例は 判定保留であった.

これらの結果を踏まえて, 治療の強化もしくは軽減を行い, そ
の後の経過を追った. 今後の課題および検査の問題点を含めてこ こに報告する。

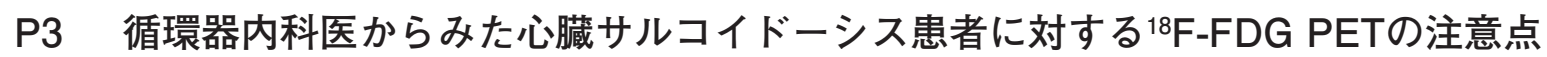

$\bigcirc$ 矢崎善一 ${ }^{1)}$, 関村紀之 ${ }^{2)}$, 越川め〈゙み ${ }^{2)}$, 笠井宏樹 ${ }^{2)}$, 伊澤 淳 $^{3)}$, 池田宇一3), 小口和弘 ${ }^{4)}$

佐久総合病院 循環器内科 1 )

まつもと医療センター松本病院 循環器内科 ${ }^{2)}$

信州大学 循環器内科 ${ }^{3}$

相澤病院 PET センター4)

${ }^{18}$ F-FDG (fluorodeoxyglucose) PETは心蔵サルコイドーシス （以下心サ症）の活動性評価に期待されているが，心筋への生理 的集積は完全には抑制できない.

【対象と方法】心サ症および疑い例30例（A 群:ステロイド投与前9 例と B 群:投与後21例：男性7例, 女性23例, 平均67歳)。 ${ }^{18} \mathrm{~F}-\mathrm{FDG}$ PET は18時間の絶食と, 前日の昼食および夕食は炭水化物制限

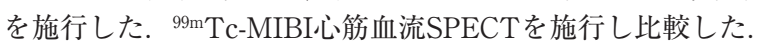

【結果】1） A 群:9例中3例が活動性病変ありと判断されプレドニ ン開始. 2) B 群:1例が99m Tc-MIBI とのミスマッチから活動性あ りと判断. 1例は蝴漫性集積, 3例は心基部の集積, 2 例が不規則 な集積を認めた． 3）炭水化物制限食を追加すると B 群の6例中5
例はFDGの心筋集積は消失. 4）高度な低心機能の1例はステロ イド投与後 ${ }^{67} \mathrm{Ga}$ の心筋への異常集積は消失したがFDGの心筋集積 は不変であった。

【結語】心サ症の病変が強い心基部よりにFDGの生理的集積が生 じやすく, 炭水化物制限食が必須である. 不全心のFDG集積に も注意すべきである. 